\title{
Advancing Sustainability of Open Educational Resources
}

\section{Alex Koohang \\ Macon State College, Macon, Georgia, USA}

alex.koohang@maconstate.edu

\section{Keith Harman \\ Oklahoma Baptist University Oklahoma, USA}

\author{
Keith.Harman@okbu.edu
}

\begin{abstract}
This paper discusses the concept of Open Educational Resources (OERs). The discussion then shift to OER sustainability, a fundamental element essential for the success of OER. Special attention is given to the following as they relate to the OER sustainability: instructional design \& presentation; cost of production and maintenance; support; and OER communities of practice as relate to scalability. The paper concludes with recommendations for OERs future research.
\end{abstract}

Keywords: Open Educational Resources (OERs), sustainability, scalability, decentralization, communities of practice

\section{Introduction}

The primary purpose of this paper is to 1) introduce readers to Open Educational Resources (OERs) and 2) discuss several vital issues as regards the OER sustainability. This paper is organized in manner consistent with its purpose. The paper's introductory remark describes OERs. Firstly, different perspectives of OERs are discussed focusing on their goals and objectives. Secondly, definitions and examples of various OER initiatives are presented.

The discussion then shifts to the OER sustainability, a fundamental element responsible for the success of OERs. Next, the discussion focuses on several vital issues as regard sustainability of OERs. These issues are instructional design and presentation; cost of production and maintenance; and OER communities of practice as relate to scalability. Conclusions and recommendations for future research round out the paper.

\section{What are Open Educational Resources?}

Open Educational Resources (OERs) are becoming increasingly popular in educational institutions. OERs include all educational resources - normally digital in nature such as learning objects, open courseware, etc. that can be freely accessed (with no cost to users) via the Internet

Material published as part of this publication, either on-line or in print, is copyrighted by the Informing Science Institute. Permission to make digital or paper copy of part or all of these works for personal or classroom use is granted without fee provided that the copies are not made or distributed for profit or commercial advantage AND that copies 1) bear this notice in full and 2) give the full citation on the first page. It is permissible to abstract these works so long as credit is given. To copy in all other cases or to republish or to post on a server or to redistribute to lists requires specific permission and payment of a fee. Contact Publisher@InformingScience.org to request redistribution permission. with minimal or no restrictions.

UNESCO (2002, Paragraph 3) defined OERs as

“... technology-enabled, open provision of educational resources for consultation, use and adaptation by a community of users for non-commercial purposes. They are typically made freely available over the Web or the Internet. Their prin- 
cipal use is by teachers and educational institutions to support course development, but they can also be used directly by students. Open Educational Resources include learning objects such as lecture material, references and readings, simulations, experiments and demonstrations, as well as syllabi, curricula and teachers' guides."

Johnstone (2005, par. 5) characterizes OERs as

- Learning resources - courseware, content modules, learning objects, learner-support and assessment tools, online learning communities

- Resources to support teachers - tools for teachers and support materials to enable them to create, adapt, and use OER, as well as training materials for teachers and other teaching tools

- Resources to assure the quality of education and educational practices

Specifically, Hylén (2005, par. 3) outlined the OER initiatives into the following categories:

1) open courseware and content;

2) open software tools (e.g. learning management systems);

3) open material for e-learning capacity building of faculty staff;

4) repositories of learning objects; and

5) free educational courses

Johnstone (2005) stated that OERs should not be perceived as degree-granting system and that OER is not a substitute for institutionally-supported open and distance learning materials. OERs are considered a means of providing access to resources that have some educational value, particularly for those with limited or no access to educational resources. In the next section the four Open Educational Resources initiatives are discussed.

\section{Open Educational Resources Initiatives}

\section{Open Courseware}

Open courseware (OCW), pioneered by Massachusetts Institute of Technology (MIT), is the open educational resources that provide free access to courses for students, educators, and self-learners. These courses are not designed for degree-granting or certificate-granting systems. The goal of MIT Open courseware is to create "... a vast network of universities around the world offering open access to high-quality educational materials in a variety of different disciplines, in a variety of different languages, creating a global Web of knowledge that will improve education around the world." (See Other Opencourseware Projects at http://ocw.mit.edu/OcwWeb/Global/AboutOCW/otherocws.htm )

Wiley (2006) asserts that over 2000 open courses are currently available online and that presently, sixteen different countries are involved in OCW initiatives. Below is a list of several OCW initiatives.

- John Hopkins School of Public Health OpenCourseWare (http://ocw.jhsph.edu/)

- Keio University's Open courseware (http://ocw.dmc.keio.ac.jp/)

- KYOTO-U's OpenCourseWare (http://ocw.kyoto-u.ac.jp/en/)

- MIT OpenCourseWare (http://ocw.mit.edu/index.html) 
- Monterey Institute (http://www.archive.org/details/ap_courses)

- OCW Consortium - A collaboration of sixty higher education institutions and associated organizations from around the world (http://ohana.mit.edu/ocwc/homepage.action)

- Osaka University Open Courseware (http://ocw.osaka-u.ac.jp/index.php)

- Rice University Connexions (http://cnx.org/)

- Sakai Project (http://sakaiproject.org/)

- Tufts OpenCourseWare (http://ocw.tufts.edu/)

- University of Tokyo OCW (http://ocw.u-tokyo.ac.jp/english/index.html)

- Utah State University OpenCourseWare (http://ocw.usu.edu/Index/ECIndex_view)

\section{Learning Management Systems}

Downes (2002) asserts that a learning content management system (LCMS) is responsible for sequentially assembling chunks of instruction into a course and that a common LCMS contains four essential pieces: 1) an authoring application, 2) a repository, 3) a delivery interface, and 4) administration tools.

A LCMS is used to create, store and reuse digital learning contents. It is also responsible for managing and delivering digital learning contents. Below is a list of several open source LCMS.

- a-LMS - Automatic Learning Management System (http://a-lms.sourceforge.net/)

- ATutor (http://www.atutor.ca/)

- Avatal Learn Station (http://sourceforge.net/projects/avatal/)

- Claroline E-Learning System (http://www.claroline.net/)

- .LRN Course Management (http://www.collaboraid.biz/products/dotlrn)

- EduZope Content Management System (http://www.eduzope.org/)

- Moodle Course Management System (http://moodle.org)

\section{Open Material for E-Learning Capacity Building of Faculty/Staff}

Successful analysis, design, development, and implementation of e-learning necessitate capacity building via open materials that can be shared, used, and reused via a community of practice. Likewise, teaching, assessment, and administration of e-learning can be strengthened via capacity learning.

Open materials for e-learning capacity building of faculty/staff can be created, used, and reused using open source e-learning tools such as Claroline E-Learning System (http://www.claroline.net), Moodle Course Management System (http://moodle.org), Online Learning and Training - OLAT (http://www.olat.org). Today, there are many open source elearning management systems that can be used for e-learning capacity building of faculty/staff.

\section{Learning Objects Repositories}

Learning object repositories are responsible for storing learning objects. Two types of learning object repositories are available - repositories that contain both learning objects and metadata in one location and repositories that contain only metadata. The learning objects for the latter are stored in other locations. Below is a list of several learning object repositories: 
- Apple Learning Interchange (http://ali.apple.com/ali/resources.shtml)

- CAREO (http://careo.netera.ca)

- Distributed Learning Object Repository Network (DLORN) (http://www.downes.ca/cgibin/dlorn/dlorn.cgi)

- MERLOT (http://www.merlot.org)

- Portal for Online Objects in Learning (POOL) (http://www.edusplash.net/)

- Wisconsin Online Resource Center (http://www.wisc-online.com/)

\section{Free Educational Courses}

Today, many Internet sites offering free educational courses to anyone who needs them. Independent of OCW initiatives, these courses are from a mix of disciplines. Examples are as follows:

- Free education on the Internet (http://www.free-ed.net/free-ed)

- Free Online courses (http://www.docnmail.com)

- World Lecture hall (http://web.austin.utexas.edu/wlh)

\section{The OER Sustainability}

\section{What is Sustainability?}

The significance of sustainability of OERs has been mentioned in the literature (Downes, 2007; Wiley, 2005). Wikipedia defines sustainability as

"... an attempt to provide the best outcomes for the human and natural environments both now and into the indefinite future. It relates to the continuity of economic, social, institutional and environmental aspects of human society, as well as the non-human environment. It is intended to be a means of configuring civilization and human activity so that society, its members and its economies are able to meet their needs and express their greatest potential in the present, while preserving biodiversity and natural ecosystems, and planning and acting for the ability to maintain these ideals in a very long term. Sustainability affects every level of organization, from the local neighborhood to the entire planet."

In the next section we discuss some vital issues related to sustainability of OERs. These issues are as follows:

- Instructional Design \& Presentation

- Cost of Production and Maintenance

- Support of OERs

- OER Communities of Practice as relates to scalability

\section{Instructional Design and Presentation}

The OERs must have some educational value. We argue that the educational value of an open digital content can contribute to its sustainability. The value of OERs can be measured by how 
well they are designed and presented. Instructional design (linked to learning theories) and presentation (associated with user interface) are vital to sustainability of OERs.

The design of OERs must include some pedagogical value. Every effort must be taken to include learning in OERs. Researchers are in consensus that learning theories and principles are conduit to the actual learning in the design of digital contents, specifically, e-learning (Hung, 2001; Hung \& Nichani, 2001; Oliver, 1999). Furthermore, research has documented that knowledge construction derived from the constructivism theory is appropriate for the design of digital contents (Bannan-Ritland, Dabbagh, \& Murphy, 2000; Harman \& Koohang, 2005; Koohang \& Harman, 2005).

Furthermore, inclusion of user interface design components such as simplicity, navigability, user control, readability, recognition, and consistency are vital in the process of designing digital contents because they help produce learning (Koohang \& Du Plessis, 2004).

\section{Cost of Production and Maintenance of OER}

Cost of production and maintenance is among the greatest concerns regarding OERs (Downes, 2007). Many OER projects are funded by private foundations. What happens to sustainability of OERs when the funds are dried out?

It seems logical that there is an inverse relationship between scalability and costs of production and maintenance. An OER should be functional. But that does not mean an OER should possess all of the "bells and whistles" available via a commercial product.

For example, Downes (2007) argues that production of OERs depends upon their sustainability. Hanley (2005) believes that the sustainability of OERs can be improved by applying a set of steps - "a traditional workflow". These steps are as follows:

Step 1: Discovery \& Research for Teaching

Step 2: Designing the Learning Experience

Step 3: Teaching

Step 4: Learning

Step 5: Feedback, Assessment, \& Evaluation

But does following this set of steps mean superior quality of OER content or is this for our own intuitive comfort?

The issue of production and maintenance of OERs is analogous to issues faced by those who develop a new product. They must design the product and they must design a way to produce it (c.f. Chase, Jacobs, \& Aquilano, 2006, Chapter 6).

One paradigm that offers assistance is value analysis and value engineering. Value analysis and value engineering techniques include ways to identify unnecessary functions or features (Chase, et al. 2006).

For example, if we argue that the level or amount of users' learning contributes to sustainability of OERs then we may assume an obligation far beyond what is feasible to assume. Contextualization of content cannot be guaranteed. A plain syllabus with notes will most likely be used by someone who sees value beyond the plain syllabus and notes. It will be ignored by or passed over by someone who sees no value. And it is fair to suggest that an OER cannot be all things to all users. 


\section{OER Support}

Downes (2007) reviews an array of options or models as regards sustainability. These include funding models, technical models, content models, and staffing models. It is likely that all of them will come into play to one extent or the other. Therefore, it would be wise to avoid "binary trap" thinking, i.e. an assumption that sustainability is a matter of the level of commercial support versus government and philanthropic support. A more appropriate assumption is to think in terms of a mix of support.

As we consider that mix we can start with a basic premise: knowledge and learning (and the products associated with them) are commonweal goods. Tacit acceptance of this premise is demonstrated by the existence of private, not-for-profit and publicly supported educational institutions of all types at all levels.

Our collective experience with other commonweal goods is instructive. Schumpeter (1935), Van Duijn (1983) and Volland (1987) argue that broad-scale technological innovation occurs in waves and eventually requires a mix of subsidies and profits. OERs are a commonweal good and they will be financially supported. That is a workable general premise but it does not mean that all OERs will be supported. Logic dictates that this is a solid assumption. Empirical evidence confirms our assumption. Christensen (1997) concluded that breakthrough technologies are often seen as "disruptive." They create what Christensen describes as "the innovator's dilemma."

Christensen argues that most firms seek to develop and to exploit "sustaining technologies," i.e. those that foster improved product performance, as perceived by the mainstream consumers of that product (1997, p.p. xiii-xxiv). Products that have gained wide acceptance therefore become a sort of paradigm. Christensen contrasts "sustaining" technologies with "disruptive" technologies:

"...disruptive technologies emerge: technologies that result in worse product performance, at least in the near term... they have other features that a few fringe (generally new) customers value. Products based on disruptive technologies are typically cheaper, simpler, smaller, and more frequently, more convenient to use." (p. xv).

Therefore, the issue of sustainability will probably not be driven by resources. It is more likely driven by factors that relate to the scalability of an OER. Scalability is the ability of OERs to continue to function properly when modified to meet the needs of users. Wiley (2005) directs the attention of the OER communities to the concept of decentralization. He asserts that decentralization improves the scalability of OERs.

\section{OER Communities of Practices and Scalability}

We agree with Wiley's position that decentralization improves scalability. We further argue that formation of communities of practice improve the scalability of OERs because Communities of practice are characteristically decentralized.

Ostwald (1996) defined a community of practice as

"A group of practitioners involved in a common activity, albeit performing different roles. Essential characteristics of communities of practice are: 1) they are not defined by organizational mandate (e.g., the "org chart"), but rather by the ways people actually work together, 2) they involve many different roles, as opposed to a flat structure, and 3) they experience an ongoing flux of community members, who enter the community from the periphery and gain status as knowledgeable members through participation in the community of practice." 
Members of a community of practice have 1) the freedom to participate, 2) the freedom to join or to leave the group, and 3) they have an interest in the creation or sharing of knowledge (Baily \& Hendrickson, 2004; Davenport \& Prusak, 1998).

Wenger (1998) sees three dimensions that define a community of practice. These are as follows:

- What it is about - its joint enterprise as understood and continually renegotiated by its members

- How it functions - mutual engagement that bind members together into a social entity

- What capability it has produced - the shared repertoire of communal resources (routines, sensibilities, artifacts, vocabulary, styles, etc.) that members have developed over time. (par. 9)

We argue that building communities of practice improve scalability of OERs. Therefore, promoting communities of practice is vital to the health and sustainability of OERs. Members of communities of practice with common interest are involved in different aspects of OERs. Their common goal is to improve the sustainability of OERs. In an OER community of practice, members have different skills and experiences. These skills and experiences can blend together to create scalable OERs.

\section{Conclusion}

The primary purpose of this paper was to introduce readers to OERs and discuss several vital issues as they relate to sustainability of OERs. After introductory remarks different perspectives of OERs were discussed; focusing on their common goals. Secondly, definitions and examples of various OER initiatives were presented.

The discussion then shifted to OER sustainability, a fundamental element essential for the success of OERs. This paper gave special attention to the following issues: instructional design \& presentation; cost of production and maintenance; support of OERs; and OER communities of practice as relate to scalability.

Sound instructional design and presentation of OERs produce learning and the learning can contribute to sustainability of OERs. The OER instructional design relates to inclusion of sound and appropriate learning theories into the digital contents. The OER presentation deals with the user interface design. Both learning theories and user interface design are imperative to learning.

The question "What happens to sustainability of OERs when the funds are dried out?" was answered in relation to quality of OER content. It was determined that the issue of production and maintenance is analogous to issues faced by those who develop a new product. The paradigm of value analysis and value engineering techniques were proposed to be effective methods in identifying unnecessary functions or features, thus reducing the cost of OER production and maintenance.

OERs are commonweal goods. Their financial support will probably include a mix of subscriptions and subsidies. The basic premise is that knowledge and learning and the products associated with them are commonweal goods and the tacit acceptance of this premise is demonstrated by the existence of private, not-for-profit and publicly supported educational institutions.

The sustainability is driven by factors that relate to the scalability of an OER - the ability of OER to function properly when modified in an on-going basis. OER communities of practice must be formed to help enhance the scalability. Communities of practice are analogous with decentralization - a factor said to improve scalability. 


\section{Future Research}

This paper recommends that the issues of instructional design \& presentation; cost of production and maintenance; OER support; and OER communities of practice as relate to scalability should be further explored.

The key questions that deserve attention for the OER instructional design and presentation are as follows:

1. What are the limits to a constructivist approach to OER design?

2. Are these limits predominantly a function of learner attributes?

3. What is the most appropriate interface design for OER?

The key question that deserves attention for OER cost of production and maintenance is as follows:

1. Does a constructivist paradigm make design a function of serendipity rather than an issue of value or perceived value?

The key questions that deserve attention for OER support are as follows:

1. How do we measure the marginal utility of an OER?

2. What is the prevailing price elasticity of OER?

The key questions that deserve attention for OER communities of practice as relate to scalability are as follows:

1. Are repertoires of communal resources shared in typical or predictable patterns?

2. What mix of member practices and skills is required for a community of practice to emerge? To be sustained?

In addition to the key questions formulated for researcher, this paper recommends that serious attention must be given to measuring the success of OERs. OER metrics flow directly from their utility. This should include data such as cost per user, cost per record, and any other utility-type measure that would be appropriate. User perspectives are vital to success of OERs. Obviously user surveys can tell us much. We recommend that future research focus on users' perspectives as regard OERs. Furthermore, studying user attributes in comparison with usage patterns has merit for research.

OERs are in their infancy. They have great potential for access to education. For the purpose of organization, retrieval, and manageability; we recommend that scholars pioneer and research the possibility of creating an intelligent large-scale Internet-based OER database that navigates all OERs available on the Internet. The OER database can also be a conceptual guide for dissemination of data for research that may improve all aspects of OERs and their sustainability.

Finally, this paper presented only several issues pertaining to sustainability of OER. Other potential emerging variables that may influence sustainability of OER must be ascertained and researched.

\section{References}

Baily, T. \& Hendrickson, S. (2004). How to grow a community of practice. The JPL Information Providers Network. Information Outlook, 8 (1), pp.12-15.

Bannan-Ritland, B., Dabbagh, N. \& Murphy, K. (2000). Learning object systems as constructivist learning environments: Related assumptions, theories, and applications. In D. A. Wiley (Ed.), The instructional 
use of learning objects: Online version. Retrieved September 21, 2005 from

http://reusability.org/read/chapters/bannan-ritland.doc

Chase, R., Jacobs F., \& Aquilano, N. (2006). Operations management for competitive advantage ( $11^{\text {th }}$ ed.). New York: McGraw-Hill.

Christensen, C.M. (1997). The innovator's dilemma: When great technologies cause great firms to fail. Boston: Harvard Business School Press.

Davenport, T. \& Prusak, L. (1998). Working knowledge: How organizations manage what they know. Boston, Harvard Business School Press.

Downes, S. (2002). Design and reusability of learning objects in an academic context: A new economy of education? USDL Journal, 17(1). Retrieved September 21, 2004, from http://www.usdla.org/html/journal/JAN03 Issue/article01.html

Downes, S. (2007). Models for sustainable open educational resources. Interdisciplinary Journal of Knowledge \& Learning Object, 3, 29-44. Retrieved from http://ijklo.org/Volume3/IJKLOv3p029044Downes.pdf

Harman, K. \& Koohang A. (2005). Discussion board: A learning object. Interdisciplinary Journal of Knowledge \& Learning Object, 1, 67-77. Retrieved from http://ijklo.org/Volume1/v1p067077Harman.pdf

Hung, D. \& Nichani, M. (2001). Constructivism and e-learning: Balancing between the individual and social levels of cognition. Educational Technology, 41(2), 40-44.

Hung, D. (2001). Design principles for web-based learning; Implications for Vygotskian thought. Educational Technology, 41(3), 33-41.

Hylen, J. (2005). Open educational resources: Opportunities and challenges. OECD-CERI. Retrieved October 27, 2006 from http://www.oecd.org/dataoecd/1/49/36243575.pdf

Johnstone, S. (2005). Open educational resources serve the world. Educause Quarterly, 28(3). Available at http://www.educause.edu/apps/eq/eqm05/eqm0533.asp?bhcp=1

Koohang, A. \& du Plessis, J. (2004). Architecting usability properties in the e-learning instructional design process. International Journal on E-Learning, 3 (3), 38-44.

Koohang, A. \& Harman, K. (2005). Open source: A metaphor for e-learning. Informing Science Journal, 8, 75-86. Retrieved from http://inform.nu/Articles/Vol8/v8p075-086Kooh.pdf

Oliver, R. (1999). Exploring strategies for online teaching and learning. Distance Education, 20(2), 240254.

Ostwald, J. (1996). Knowledge construction in software development: The evolving artifact approach. Unpublished Ph.D. Dissertation, University of Colorado at Boulder, Boulder, Colorado, USA.

Schumpter, J. (1935). Business cycles: A theoretical, historical and statistical analysis of the capitalist process. New York: McGraw-Hill.

UNESCO. (2002). UNESCO promotes new initiative for free educational resources on the Internet. Retrieved October 27, 2006 from http://www.unesco.org/education/news en/080702 free_edu_ress.shtml

Van Duijn, J. (1983). The long wave in economic life. Boston: Allen \& Unwin.

Volland, C. (1987). A comprehensive theory of long-wave cycles. Technological Forecasting and Social Change, 32(2), 123-145.

Wenger, E. (1998). Communities of practice: Learning as a social system. Retrieved October 30, 2006 from http://www.co-i-1.com/coil/knowledge-garden/cop/lss.shtml

Wikipedia. (n.d.). Definition of sustainability. Retrieved November 2, 2006 from http://en.wikipedia.org/wiki/Sustainability 
Wiley, D. (2005). Thoughts from the Hewlett Open Ed Grantees meeting. Retrieved September 10, 2006 from http://opencontent.org/blog/archives/192

Wiley, D. (2006). The current state of open educational resources. Retrieved September 16, 2006 from http://opencontent.org/blog/archives/247

\section{Biographies}

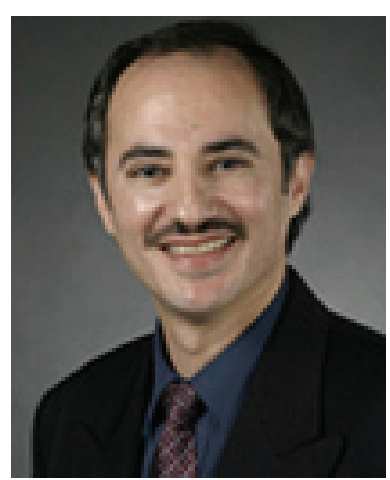

Alex Koohang is Professor of Information Technology and Chair of the Division of Information Technology at Macon State College, Macon, Georgia, USA. Dr. Koohang has published and presented numerous scholarly articles and monographs. He serves as the Editor-inChief of the Interdisciplinary Journal of Knowledge and Learning Objects. He is also the senior editor of Interdisciplinary Journal of Information, Knowledge \& Management. Dr. Koohang is a Fellow at the Informing Science Institute. He has won a number of awards in recognition of his dedicated commitment to service, research, and leadership in the field of Information Technology. Dr. Koohang's current research interests are in the areas of learning objects, open education, open access, open source, e-learning, and knowledge management.

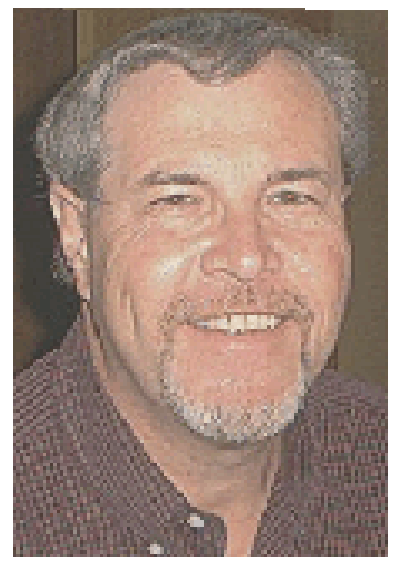

Keith Harman, is professor of Business at Oklahoma Baptist University. Dr. Harman's 25 years of experience in academe include stints as a faculty member, department chairperson, dean, and academic research administrator. In addition to three books on information management and strategic planning and over two dozen publications and presentations in journals and proceedings, he has served as a guest lecturer and consultant for Fortune 1000 corporations, major universities, private foundations and government agencies. 